\title{
The Analysis of Communication Strategies of North Luwu Regency Government in Socio-Economic Recovery After Landslides and Flash Flood
}

\author{
Muh. Taufik Rahmansyah Abdullah*, Hafied Cangara, Arianto \\ Fakultas Ilmu Sosial dan Ilmu Politik \\ Universitas Hasanuddin \\ Makassar, Indonesia \\ *Taufikr132@gmail.com, Cangara_hafied@yahoo.com, arianto.92komunikasi@gmail.com
}

\begin{abstract}
After the natural disaster of landslides and flash floods that occurred in the North Luwu Regency area, it had destroyed 6 sub-districts (Baebunta, Sabbang, South Baebunta, West Malangke, Malangke, and Masamba Sub-districts), apart from causing casualties, these events have hampered the socioeconomic as well as a sustainable development plan. Although communication cannot change socio-economic conditions directly, the implementation of an effective communication strategy can encourage coordination, information, and cooperation in solving problems. So this study aims to analyze the strategy of the North Luwu Regency government in carrying out socio-economic recovery after the disaster of flash floods from the perspective of disaster communication. Where the researchers only took one of the sub-districts with the worst level of damage, namely Masamba District. The research method used is qualitative through a case study approach. Researchers used purposive sampling in determining the collection of data sources. The results of this study indicate that there is a communication strategy in socio-economic recovery after landslides and flash floods in North Luwu Regency which is experiencing a weakening. Besides that, to restore socio-economic status, the North Luwu Regency government also utilizes technology and social media in the digitalization era, in resurrecting adversity due to disasters. the existence of a communication strategy in socio-economic recovery after landslides and flash floods in North Luwu Regency which is experiencing a weakening.
\end{abstract}

Keywords-strategy, disaster communication, socio-economy, post-disaster recovery, north luwu regency

\section{INTRODUCTION}

Disasters always cause casualties and even almost every year natural disaster events such as earthquakes, landslides, flash floods, hurricanes, and tsunamis are natural events that are difficult to predict because every natural disaster event certainly has the characteristics and magnitude of the impact. This is of course also experienced by various countries, not only in Europe but also in Indonesia. In Indonesia, the rules related to disasters have been regulated in Law Number 24 of 2007 concerning disaster management which explains that disaster is a series of events that can cause casualties, threaten life, damage environmental ecosystems, weaken socioeconomic pillars, and even have an impact on human psychology.

This research has certainly been done by many previous researchers, as well as research conducted by [1] with the title "Communicating with communities $(\mathrm{CwC})$ during post-disaster reconstruction: an initial analysis" which presumably this research discusses the role of communication when humans are faced with disaster management situations which are considered an integral part of humanitarian assistance. There are also similar studies, namely [2] entitled "Social Dimensions of Disaster Recovery", this study shows that research on disaster recovery can be said to have moved beyond conceptualization between dimensions, towards an approach that recognizes social variability, inequality, and diversity. In addition, the research conducted by [3] with the title "Communication with disaster survivors: Towards best practice". This research is based on one of the most horrific terrorist attacks that have ever occurred in the United States, namely the attack on the World Trade Center (WTC) tower or better known as the attack on 9/11. The use of communication to assist the recovery of the victims of the New York and London tragedies. What this research has in common lies in the communication strategies employed by the institutions and individuals involved in assisting the recovery of survivors. The difference is that this research is about non-natural disasters while the author is more concerned with natural disasters and on the other hand, the object and focus of the research are different.

On Monday, July 13, 2020, Masamba Sub-district, North Luwu Regency is experiencing the brunt of landslides and flash floods which are the most powerful natural disasters in 2020, because they can ravage the community and also the government, causing a downturn, even harmony, and management of life. Of course, it cannot be felt the same as the time before the disaster occurred. Originally peaceful life seemed to disappear in an instant. Day after day they live full 
of the burdens of life, establishing communication with the local government is a difficult thing for them to do, even they are waiting for the intake of recovery from the power holders.

In the event of a natural disaster, of course, there is a law of causality, which can be caused by nature or humans themselves. Where the main cause of the occurrence of landslides and flash floods is due to the influence of climate anomalies that trigger abnormally high rainfall intensity, so that it has an impact on three large rivers that overflow rapidly, because the three rivers are not sufficiently able to withstand the hydrological load of water, including rivers Meli in Baebunta District, Rongkong River in Rongkong District, and the Masamba River in Masamba District. The estimated loss caused by the disaster was quite large, namely \pm Rp. 7-8 Trillion. So that in the context of a disaster, it makes sense that the post-disaster recovery domain is important to realize, in maintaining life activities.

The Government of the Republic of Indonesia in this case BNPB sees that the natural disaster of landslides and flash floods that occurred in North Luwu Regency is a natural disaster which is categorized as a National natural disaster so that the information submitted by BNPB makes all news media (local, national and international) flocked to come to the disaster site. This is because the facts on the ground cannot be underestimated, which proves that there is a frenzied search for information from the survivors, their families, the local government, and even various disaster response agencies. So, to meet the need for information, people often seek information through the mass media, authorities, local governments, or other community members as the main source in disaster management. Then Figure 1.1 below will explain the number of losses experienced after the disaster:

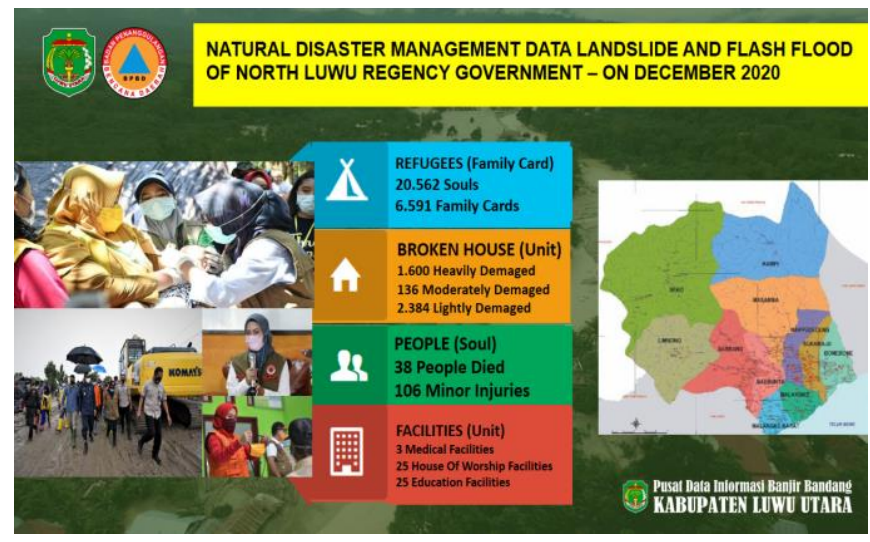

Fig. 1. Data on loss after flash flood disaster in North Luwu regency.

Based on the figure 1 above, in addition to causing casualties, landslides and flash floods may be able to have a panic effect on the governance of people's lives, even being able to change the socio-economic conditions of people who have experienced a significant decline, including from the aspect of education, religious activities, community housing, the need for clean water/electricity, health, food crop commodities, plantation crop commodities, industrialization, even trading commodities or SMEs [4].

From the magnitude of the impact caused by landslides and flash floods, effective disaster risk management depends on how involved all stakeholders are, which disaster management can be said to be an effort of massive humanitarian activities. Where, the government certainly has more capacity and resources on paper related to the ability to deal with disasters [5]. Although communication cannot completely change the socio-economic conditions directly. However, the availability of communication aspects in disaster management can certainly be taken into account by every stakeholder and disaster management institution. The research conducted by [6] says that. in disaster literacy, placing communication within the scope of the disaster, is certainly something new. Because apart from being used in emergency response conditions, communication can also be implemented in the process of disaster mitigation, information dissemination, and postdisaster reconstruction. Therefore, communication can be the first step in determining a policy.

Credibility, attractiveness, charisma, accuracy, and expertise which is one of the models of approach contained in the scope of communication. Where this is also a supporting factor in determining cleanliness, especially when dealing with post-disaster. The success or failure of disaster management will certainly be sustainable with the socio-economic benefit of the community. In addition, the government must be able to collaborate between disaster disciplines and disaster communication strategies, either directly or indirectly. According to Berger [7], explained that there are three approaches in forming a strategy, namely passive, active, and interactive strategies.

The term strategy is no longer a new thing for the North Luwu Regency government, which is a strategy used to formulate the best management in achieving goals. On the other hand, strategy is a tactic, and tactics are part of the strategy, with tactics, strategies can be designed, it can be said that strategy is a guide in making tactics, and tactics are a real form of strategy. Although strategies and tactics are different, they are very closely related to each other. So, a communication strategy is a series of actions with a good plan to achieve the initial goal, using methods, techniques, and other analytical approaches from a communication perspective [8]. The magnitude of the impact caused by this disaster made the authors see that in every post-disaster socio-economic recovery agenda that occurred in North Luwu Regency, of course, it was not just working and work, but also a strategy and a measurable communication process to balance the performance. Performance without a communication process will certainly present obstacles or uncertainty. Therefore, to find out the actual condition of a problem, the best step is to enter or be directly into the situation, considering the conditions that occur in North Luwu Regency are very attention-grabbing and must be studied not only from a disaster perspective but also from the perspective of communication as the most important aspect in every activity. Post-disaster handling, in this case, is related 
to communication strategies, by looking at the extent of the communication process that runs in addressing any problems that occur whether it is who conveys it, what kind of message is conveyed, the communication channel or media used, and the resulting influence to the audience. This prompted the author to raise the discussion, What is the communication strategy used by the government of Masamba Sub-district, North Luwu Regency in socio-economic recovery after landslides and flash floods?

\section{RESEARCH METHOD}

This research uses descriptive qualitative methods with a case study approach, where this research can be regarded as one of the social research methods that discuss special situations that are present in a limited manner, and investigates phenomena in real-life contexts, whether individuals, organizations, communities, small groups. , an area even a country though[9]. The researcher acts as the main instrument, who is directly involved in the research location, in addition to qualitative research, it certainly cannot be separated from the observation technique, in-depth interviews, and documentation in completing all research data [10].

\section{A. Data Sources and Data Collection Techniques}

In this study, there are two sources of data, namely primary and secondary data. The primary data source of this research is the government of North Luwu Regency, the data is obtained through observation and in-depth interviews conducted in a joint environment of the North Luwu Regency official office. In addition, there are also secondary data, namely from documentation and sources of literature studies which are of course related to research problems. In determining the informants, the researcher used a purposive sampling technique which could assist researchers in fulfilling the required research data.

\section{B. Data Analysis Method}

From the data collected, then an analysis is carried out using qualitative data analysis techniques, namely the Miles and Huberman model [11]. Where in the first stage, the attitude of the researcher was to collect as much data as possible both directly and indirectly, seen and even heard about the government's strategy during the disaster in North Luwu Regency, especially in post-disaster socio-economic recovery until the data collection was considered credible, then there is data reduction, in data reduction a simplification is carried out on important matters related to the research problem, then there is a presentation of the data, wherein this process classification is carried out and finally a conclusion is drawn based on the narrative structure that has been done previously to answer all the problem researches. So the picture below is a data analysis model for Miles and Huberman (see in figure 2):

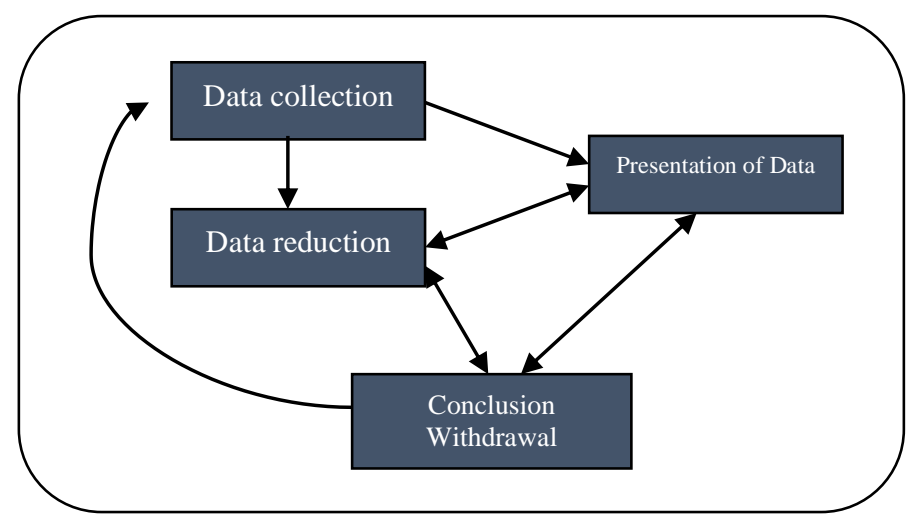

Fig. 2. Miles and Huberman's model analysis.

\section{RESULTS AND DISCUSSION}

A. Changes in Post-Disaster Socio-Economic Condition

Landslides and flash floods that occurred certainly destroyed everything. Where landslides and flash floods are classified as disasters with the worst level of damage. Changes in the socio-economic conditions of the people of Masamba Sub-district, North Luwu Regency also experienced a significant decline due to the landslide and flash flood natural disasters. Then the explanation of landslides and flash floods will be described as follows:

1) Landslide: An event caused by the movement of the mass of soil and rock layers, which originates from the highlands that descends the settlements of residents. The thing that causes landslides is that there are two factors, namely natural factors in the form of erosion due to high sea waves that erode the legs of the slopes, even occurring due to earthquakes. In addition, there are also human factors, where there is negligence caused by human intervention, such as mining activities, cutting, and illegal construction so that landslides can occur.

2) Flash flood: Is a state of submerged area or land due to a significant increase in water volume. Floods can occur due to a lack of public awareness not to live by the river[12]. The causes of flooding, namely the occurrence of climate change, lack of water catchment places to the lack of human awareness to protect the environment, because of human actions have been out of the provisions of nature. Humans do not understand how nature takes care of them, but they are not able to take care of nature.

From data [13] Astronomically, North Luwu Regency is located between 010 53' 19" - 020 55'36" South Latitude and 1190 47' 46" - 1200 37' 44" East Longitude. Based on its geographical position, North Luwu Regency has boundaries: Central Sulawesi in the north, West Sulawesi and Tana Toraja in the west, and Luwu and Bone Bay regencies in the south, North Luwu consists of 15 sub-districts namely: Sabbang District, South Sabbang District, Baebunta District, South 
Baebunta District, Malangke District, West Malangke District, Sukamaju District, South Sukamaju District, Bone-Bone District, Tanalili District, Masamba District, Mappedeceng District, Rampi District, Rongkong District, Seko Distric.

The depravity of the government system and public awareness of the importance of protecting the environment began to be neglected. Disaster does not necessarily come without any intervention behind the law of causality (cause and effect). The large population of people who live in Masamba Sub-district, North Luwu Regency certainly makes them trying to be able to rise from adversity. We know that before the disaster hit the area, there was a flow of socio-economic life, which is a condition that describes the axis of people's lives that are very important in living life. However, the enormity of the disaster caused a shift in the socio-economic conditions of the people of Masamba Sub-district, North Luwu Regency, which was experiencing a downturn, to the point of attacking various sectors.

The results of the researcher's interview with the Masamba District government stated that during post-disaster management, we have not been able to work optimally, because the District is waiting for other policies to be implemented by the regent. In addition to budget preparation, the local government is also conducting data collection and further studies so that in the process of socio-economic recovery, all victims get the right they should. The cause of this disaster also came from three major rivers, and one of them was in Masamba District. Besides that, Masamba Sub-district is the capital of North Luwu Regency, where most of the government, industrial, and trade activities are carried out in Masamba, so it may be very felt if Masamba District feels the impact.

Many people's property was lost because of this disaster, some of the people of Masamba Subdistrict worked as farmers and traders and the rest were manual laborers and civil servants, on the other hand, the burden of the head of the family at work, the mothers who had been taking care of the household also found it difficult to provide the best food. for their families, it is difficult for students to carry out the learning process, some facilities and infrastructure are damaged by the disaster, and even other sectors also experience similar obstacles. Looking at the conditions on the ground, the community feels the downturn. Assistance from various parties would be of added value in facing trials like this. According to one of the victims, they also do not have ownership of goods such as bicycles, clothes, motorbikes, television, radio, and cellphones, so.

Everything experienced a downturn due to the disaster, apart from damage to infrastructure, the need for clean water and electricity was hampered, thousands of building units were destroyed, with criteria (heavy, light, and minor damage) including religious activities. who still lives in his house, namely in Masamba Sub-district, North Luwu Regency. In addition, some fled to the homes of family and relatives to avoid further disasters. On the other hand, health intake is also something that must be considered, because, during a disaster like this, there are toddlers, children, and the elderly who experience decreased body immunity, which can be contagious or transmitted.

When the disaster hit Masamba Sub-district, North Luwu Regency, some educational facilities and infrastructure were destroyed, which resulted in changes in conditions in the education system. Based on Law Number 20 of 2003 concerning the National Education System, explains that education is a form of awareness in realizing a learning process situation so that it can develop self-potential, such as creating personality, intelligence, noble character, religious values, social values, and self-control. So education is a must when you want to develop insight, especially in science. Because considering the magnitude of the impact caused by this disaster is very large, this can certainly make you always prepare yourself when you are facing difficult situations such as the disaster of flash floods. In a major disaster situation such as a flash flood, it certainly has a big loss. So that the economic turnover in the Masamba Sub-district, North Luwu Regency exp/erienced a drastic weakening. The economy is one of the most important sectors in the context of a disaster because all forms of livelihood exist in this sector. The decline in income made the community slumped, due to the weakening of the circulation of money they experienced, on the other hand, their source of livelihood was in the agricultural, plantation, selling sectors, which suffered enormous damage.

\section{B. Communication Strategy in Socio-Economic Recovery by the Governmenti of Masamba Sub-District, North Luwu} Regency

Seeing changes in the socio-economic conditions of the people of Masamba Sub-district, North Luwu Regency, they experienced a slump. This requires the government to have good credibility, trust, coordination, and even cooperation when it comes to making a maximum handling system. Because the socio-economic recovery carried out by the government must take into account both quantity and quality aspects. The Masamba Sub-District Government of North Luwu Regency as the main actor, of course, has created in disaster management, one of which can involve various parties to present a line of coordination between internal and external parties, such as local officials, communities, volunteers, and even other institutions. Besides policymakers, they must also protect the community from all forms of threats and disasters. Given the need for the best strategy in disaster management. In addition to collecting disaster data, implementing a communication strategy in post-disaster socio-economic recovery is the right thing to do. Based on the results of the research found, the authors would be able to produce findings of communication strategy models in socio-economic recovery after landslides and flash floods in Masamba District, North Luwu Regency.

As with the duties, functions, and responsibilities of the North Luwu Regency government, identifying problems is one of the tactical steps or the first step in collecting data to 
investigate the root causes of flash floods and landslide disasters related to losses and their causal factors. In the context of communication strategy, proper and accurate analysis can be the basis for the North Luwu Regency government in formulating communication policies and actions taken in the post-disaster management process including the material to be delivered, of course, this is expected to be able to build public trust which is very important to do and coordinate. The picture below will illustrate the communication strategy, namely:

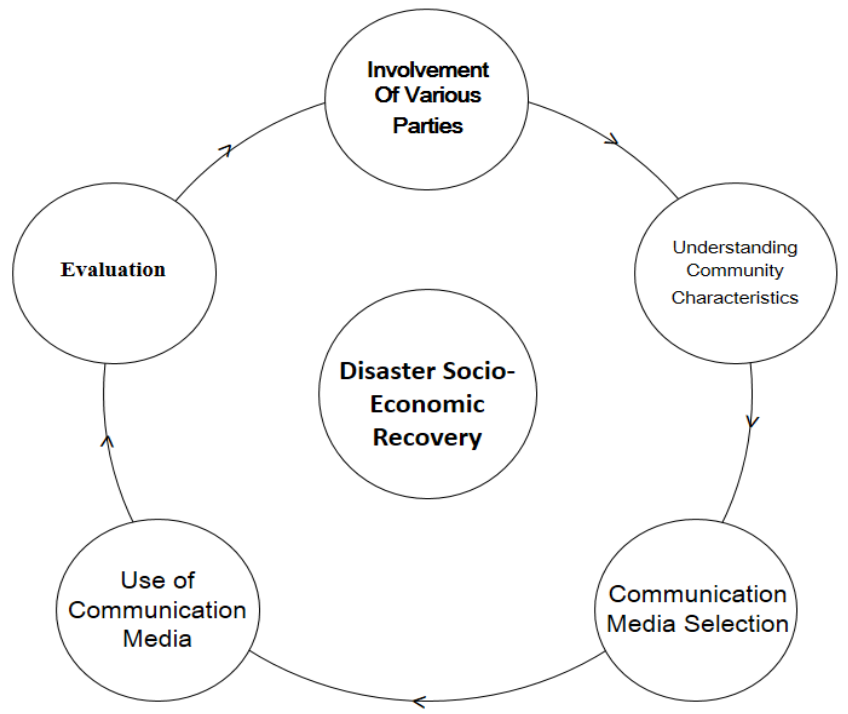

Fig. 3. Disaster communication strategy model in post-disaster socioeconomic recovery in Masamba sub-district, North Luwu regency

From the figure 3 above, it can be explained that:

- The involvement of parties, such as the SKPD and the Regional Disaster Management Agency of North Luwu Regency, carried out massive data collection regarding the death toll, the amount of damage, and other things related to the disaster. This will make it easier to carry out rehabilitation, reconstruction, and socio-economic recovery.

- Understanding the characteristics of the community, the element of locality is felt at this point, where they still maintain traditional culture. To put things as they should.

- Selection of communication media, directly and indirectly, so that all matters relating to recovery can be disseminated to the public so that later the community can understand the form of socio-economic recovery carried out by the Masamba District government, North Luwu Regency.

- The use of communication media, in this context as explained in the second point, we know that some people in Masamba District still lack technological knowledge in the sense that the use of traditional communication tools is still felt so that the use of direct and indirect communication media can be used such as providing direct socialization to the public. the community regarding post-disaster recovery steps and the installation of motivational billboards so that people can rise from adversity.

- Evaluation, at this point, observes all forms of aspects that can become inhibiting factors and supporting factors in post-disaster socio-economic recovery.

Regarding disaster management, it is known that humans are creative actors of their social reality, humans actively develop themselves through responses to stimuli in their cognitive world. [14]. In the post-disaster socio-economic recovery, everything must be prioritized to be an opportunity to continue the sustainable development plan, to normalize the socioeconomic to support the living conditions of the people of Masamba Sub-district, North Luwu Regency. On the other hand, the current era of modernization makes the development of science develop very rapidly. Collaboration between disciplines is also increasingly felt, we know that communication science is an applied social science born from various disciplines, so that communication science can synergize with other sciences, such as the field of disaster science. Implementing a science in the post-disaster socioeconomic recovery process is certainly very calculated. Where several forms of socio-economic recovery will be carried out by the Masamba District government, North Luwu Regency, one of which is to provide socialization regarding guidelines for productive and safe teaching and learning processes after the disaster, with the aim that education continues to run as it should. In addition, the North Luwu Regency Government also encourages farmers and MSME actors to be technology literate and enter the digital economy, because today's potential must be modern and follow technological developments by utilizing smartphones and social media for economic strengthening.

\section{Disaster Communication Strategy Concept}

Communication strategy can be said as the first step in carrying out an action, which is carried out through various careful considerations, so as not to cause chaos in the implementation process. One of the elements contained in a disaster communication strategy is the use of communication methods, techniques, and approaches, which can later become initial planning activities for the creation of the desired goals. According to Berger [7]In the communication strategy, there are three approaches, namely, passive, active, and interactive. Of the three approaches, of course, can be a process approach in dealing with disasters. The stages contained in the disaster communication strategy, namely: the analysis stage, the planning stage, the production stage, the implementation stage, and the evaluation stage.

Disasters can be divided into three types, namely: Natural Disasters, which are a series of events beyond human intervention, such as (earthquakes, tsunamis, volcanic eruptions, floods, volcanic eruptions, droughts, hurricanes, and 
landslides). Non-natural disasters are a series of non-natural events, which are caused by humans themselves (disease outbreaks, epidemics, failed technology, and failed modernization). Social disaster is a series of events caused by human activity itself, including social conflicts between groups or between communities, even terrorism.

Recalling a series of natural disaster tragedies that are heartbreaking and cause adversity to the community, such as the earthquake in Aceh (2004), the earthquake in Yogyakarta (2006), the Lapindo Mudflow in Sidoarjo (2006), the earthquake in Papua (2006), and floods. bandang district in North Luwu-South Sulawesi (2020). These various disasters are one of the messages that nature has given to very clear humans and give an extraordinary downturn on sustainability and even security in living life.

Natural disasters seem to have been embedded in all layers of our sense of hearing, even disasters are a necessity that is difficult to avoid. Where there is an aspect of the destiny of the creator which leads to the fatalistic values of the ancestors when they are facing a disaster. Indonesia is a country that has a high level of vigilance, due to the vulnerability of natural, non-natural, and social disasters, and it can be said that this is certainly an annual disaster. The involvement of various factors can be one of the main causes, which would require a discipline of disaster science. We all understand that the discipline of disaster science is currently developing, where there are two paradigms, namely carrying out disaster management through structural and non-structural approaches.

In the introductory book of Communication Science [15], explained that there are difficulties in establishing a definition of communication, because the development of communication science is heavily influenced by disciplines that have contributed and input, for example, sociology, psychology, electronics, anthropology, political science, linguistics, management, and so on. From a series of events that occurred in Indonesia, placing communication in the field of disaster is certainly appropriate, where its emergence is also starting to develop because until now the importance of awareness of the existence of communication is increasing, to avoid direct and indirect misunderstandings in disaster management. According to Frank Dance [16], One of the important aspects of communication is the concept of uncertainty reduction. Presenting communication in meeting needs, minimizing uncertainty, taking action as effectively as possible when interacting personally or publicly, to protect or strengthen ego ownership. Communication can become more essential when it contributes to the process of handling natural, non-natural, and social disasters.

For disaster situations such as landslides and flash floods, of course, a strong prevention cycle is needed in terms of communication, information, and leadership aspects that have integrity in mobilizing existing resources. The Incident Command System (ICS) is a system that has been structured in developing fast, precise, and targeted response activities related to handling any disaster, which has the authority to mobilize multi-departmental and multi-sectoral activities that have relevance to remain focused on humanitarian emergency actions. According Green III [5] explains the role of information, namely that in a disaster situation there are various data and various inputs, where the data can be of more value for the success of disaster management. Then the picture below will illustrate the communication mapping in a disaster event:

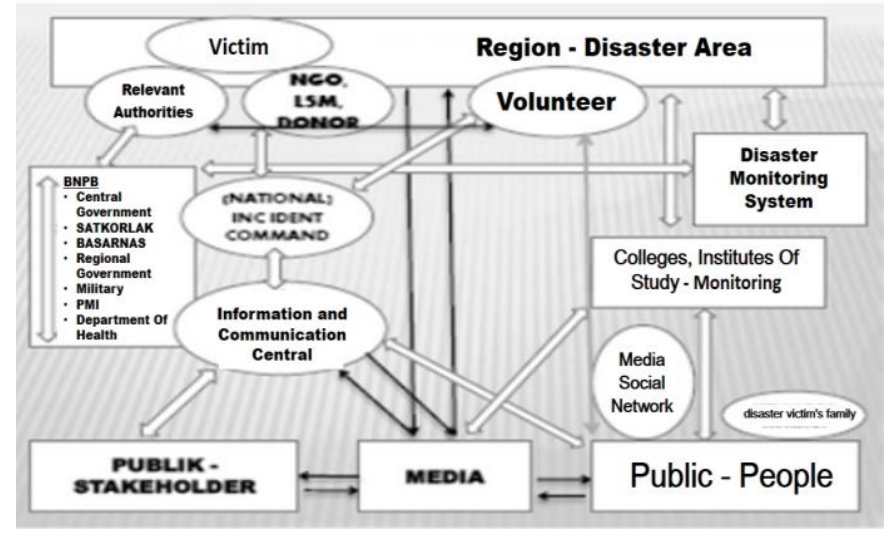

Fig. 4. Mapping of communication in disaster events.

Based on the picture above, we see that the direction of the arrow certainly describes coordination between lines. According to [5] in the disaster communication book, explains that there is potential for interactions, relating to coordination, information, communication, and cooperation (KKIK). Where shows the existence of a verification process, so as not to confuse the disaster management process. In disaster management, of course, it must be supported by various equipment, both through skills to reduce prolonged risk. These skills can be in the form of soft power or hard power, where soft power can be in the form of providing information in the context of socialization or direct or indirect communication related to disaster management. In addition, hard power is like providing provisions to act when dealing with disasters and even post-disaster through physical development, such as the construction of communication facilities.

Referring to the legality of disasters, disaster management is not only limited to providing social assistance in the form of material but also requires moral support which should also have become a necessity between human beings. coordinating disaster messages in an integrated manner may not be easy enough to do together, because there are bad habits planted by stakeholders, namely reducing or adding messages that often haunt the disaster management process. In the process of approaching disaster management, disaster communication is needed, so there are five stages in building disaster communication, namely [17]:

- Customer focus, Understand the information that the communicant wants to need (community and volunteers) build a communication mechanism that can ensure the delivery of accurate and precise information. 
- Leadership commitment, The active role of a leader during disaster response can create a commitment.

- Inclusion of communication is in planning and operations, The part in charge of all emergency planning and operation systems, in ensuring the dissemination of information communication, whether it is timely and accurate when taking an action.

- Situational awareness, Which is fundamental to effective communication, namely, collecting, analyzing, and disseminating disaster information. And holding the principle that there is transparency and can be trusted.

- Media partnership, A well-established collaboration through various media such as newspapers, radio, television, and other media is the most important medium in disseminating the right information to the public.

1) The role of media in disaster management: The digitalization culture has become popular to this day, namely media, because media has become a primary need for all audiences, from children, teenagers to the elderly. We must play an active role in eradicating information that is not following the original news. As for research[18]said that giving trust can help improve the appropriateness of the information in the eyes of people affected by disasters, and in improving the overall quality of the communication process, especially in the efficiency of the information search process. So that the position of the media in disaster management is of course very crucial, in addition to being the center of the spread of information-communication flows, errors in writing can also be a big problem. On the other hand, the media can also be a therapeutic drug for disaster victims, where there is direct and indirect communication.

Regarding the role of the media in disaster management, there are studies conducted by [19] with the research title "Community Perceptions about the Role of Local Print Media in Natural Disaster Mitigation", this study aims to look at public perceptions in translating the role of media in disaster mitigation. In addition, in the current era of modernization, people's curiosity is quite high. Where all information can be accessed easily. Of course, from various information dissemination, the participation of the government and related institutions is also very much needed, so as not to cause messy information due to someone's actions. In addition, in other cases conducted by researchers [20], which is a natural disaster of smog that has occurred in various parts of Indonesia since 2015 and even the government has designated it as a national tragedy. Many efforts were made to overcome this crisis due to the provision of public information. On the other hand, there have been many angry public statements and discontent, so that the use of social media plays a very important role in providing information networks to the public, which are handled directly by non-governmental organizations engaged in rapid response actions. This is because social media is so broad and easy to reach the wider community. It has high accuracy and simplicity in expressing an effective message.

\section{Stakeholder Involvement in Post-Disaster Recovery}

Communities in an area certainly have various characteristics, where there are children, teenagers, the elderly, to the elderly. So that the government must pay more attention to the condition of its people when it wants to create prosperity for the region, the welfare of the community in this case socioeconomic is an obligation and responsibility for every government, especially when an area is being affected by a disaster.

The government as a policymaker, of course, must be able to respond quickly in seeing the extent of the condition of the region and its people. Because, one of the duties and roles of the government is to protect its people from all threats, including disasters. So, in Law number 24 of 2007 concerning disaster management and Law number 32 of 2009 article 1 paragraph (1) and (2) related to environmental protection and management. Thus, the active role of the government and the community is needed, especially regarding the benefit of future living conditions. Air, land, forests, and others are natural resources owned by humans when they are living their life. However, good natural resources will depend on how they are managed, because if natural resource management is bad.

Disaster management certainly has legality and is the responsibility of the government. Often in disaster management, there are convoluted regulations which slow down the handling process [21]. It is known that disasters that occur must be responded to quickly, considering the magnitude of the impact. The active role of the government is certainly needed, considering that the 1945 Constitution affirms that one of the fundamental ideas and ideals of the formation of the Unitary State of the Republic of Indonesia is "to promote the general welfare and to realize social justice for all Indonesian people". In handling disasters, it will take up a lot of resources to carry out socio-economic recovery after the disaster occurs. So, as for the role of the government in dealing with disasters, namely:

- Role in determining policy.

- Role to build strategy.

- The role of being an audience communication tool.

- Role as a community therapy tool in disaster management

\section{E. John Middleton's Social Campaign Communication Planning Model}

Knowing that the importance of communication and information for the community to provide education related to disaster management. In the context of early warning, people have increased awareness of disasters. Messages that have been used so far are also included in the information domain. As the government has done in building a technology-based 
communication network, there are still small problems that are difficult to avoid. To minimize the spread of false information, the thing that must be handled is socialization to the public. Where to see the situation that occurred after the disaster, of course, presents an attitude of social concern among fellow human beings in the refugee camp.MJohn Middleton's social campaign communication planning model can be used both nationally and locally. Such as campaigning for the urgency of environmental pollution to nature, socialization of community skills empowerment, and direct or indirect interaction with affected communities. So there are ten important points in this model, namely:

- Base-line data collection and need assessment

- Formulation of communication goals

- Planning analysis and strategy development

- Audience analysis and segmentation

- Media selection

- Message design and development

- Management planning

- Implementation of training

- Implementation or implementation

- Program evaluation

Then the picture below will provide an overview of John Middleton's communication planning model, namely:

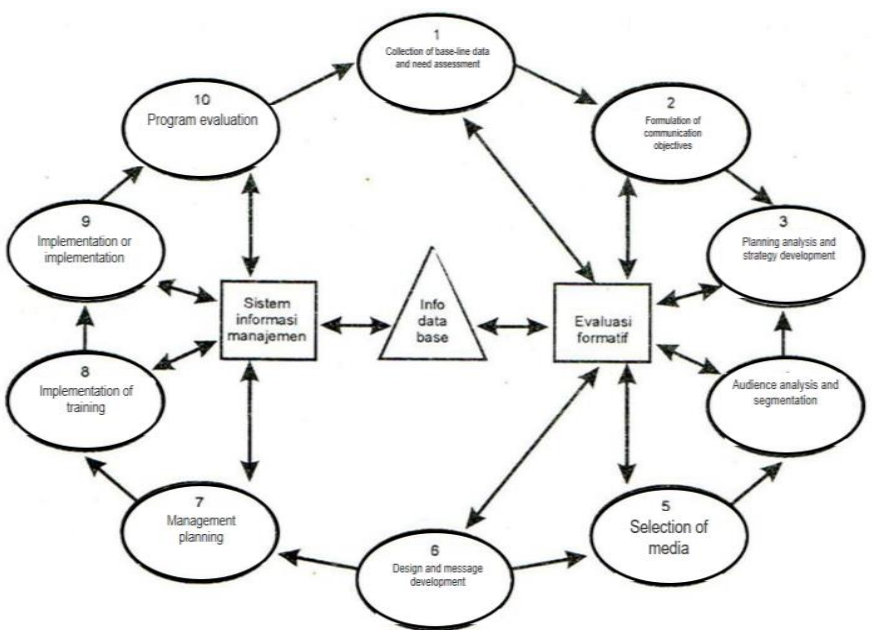

Fig. 5. Social campaign model by John Middleton.

The social campaign communication model designed by John Middleton is indeed different from other communication models. John Middleton [22], describes a process of determining communication resources to achieve the goals of an institution or organization. Where the existence of communication resources does not only include mass media or interpersonal communication. However, all forms of activities that involve changing behavior and empowering certain skills, individuals, groups, or communities within the scope of work are certainly mandated by the organization.

\section{CONCLUSION}

We know that communication is not fully capable of changing post-disaster conditions, but communication can make its contribution to the disaster management process because so far communication has only been used in emergency response situations. However, today's communication can be used in various disaster management sectors, be it in terms of disaster mitigation, rehabilitation, or post-disaster recovery. Collaboration between communication science and disaster science is a collaboration that can produce strategies in the context of disaster management.

What happened in Masamba Sub-district, North Luwu Regency was the most powerful event in 2020. Changes in socio-economic conditions were also felt. Where landslides and flash floods are disasters that are classified as extreme because they can bring a downturn for the people of Masamba Subdistrict, North Luwu Regency. The impact is extraordinary, where the socio-economic aspect is also the target. Society and government can only surrender to the existing conditions. Establishing a policy is indeed a difficult thing to implement, especially in a post-disaster socio-economic recovery situation. Various institutions have to work extra, to restore better conditions for the future. The crucial thing that often happens in disaster management is communication.

The results of this study, in the process of socio-economic recovery after landslides and flash floods in Masamba Subdistrict, North Luwu Regency, there is an application of disaster communication strategies, where the communicant to the communicator plays its role, namely the regent as the leader, of course, must involve various parties, then observe and analyzing the characteristics of damage experienced by disaster victims-community, then selecting media in the recovery process, the use of media must also be a concern because not all affected communities understand technology when all these aspects are carried out, the last stage carried out in the communication strategy is evaluation, when you want to know what supporting and inhibiting factors are in the postdisaster recovery process.

\section{REFERENCES}

[1] S. Tagliacozzo and M. Magni, "Communicating with Communities (CwC) during Post-Disaster Reconstruction: An Initial Analysis.," wNatural Hazards, vol. 84, no. 3, pp. 2225-2242, 2016.

[2] K. Tierney and A. Oliver-Smith, "Social Dimensions of Disaster Recovery," Int. J. Mass Emerg. Disasters, vol. 30, no. 2, pp. 123-146, 2012.

[3] S. Nicholls and C. dan Healy, "Communication with Disaster Survivors Towards Best Practice," Aust. J. Emerg. Manag., vol. 22, no. 4, pp. 14 20, 2007. 
[4] Q. Asy’ari, “Analisis Dampak Sosial Ekonomi Pasca Bencana Di Kabupaten Pamekasan (Studi Kasus Banjir, Longsor Dan Kekeringan Di Pamekasan 2007)," J-Macc, vol. 1, no. 2, pp. 153-168, 2018.

[5] S. Budi, Komunikasi Bencana, Pertama. Yogyakarta: Buku Litera; BPC Yogyakarta, ASPIKOM, 2011.

[6] Z.M. Muktaf, "Studi Literasi Bencana Dalam Perspektif Ilmu Komunikasi," Apik Ptm, pp. 1-12, 2017.

[7] R.W. Griffin, Bisnis. Jakarta: Erlangga, 2006.

[8] A. Suherman, "Strategi Komunikasi Bencana Pada Masyarakat Kabupaten Buton Selatan," Medialog J. Ilти Komun., vol. 1, no. 2, pp. 10-18, 2019.

[9] R. Yin, Studi Kasus Design \& Metode, Revisi. Jakarta: PT Raja Grafindo Persada, 2012.

[10] J.W. Creswell, Research Design (Pendekatan Metode Kualitatif, Kuantitatif, dan Campuran), KE EMPAT. Yogyakarta: PUSTAKA PELAJAR, 2014.

[11] Sugiyono, Metode Penelitian Kuantitatif Kualitatif dan R\&D. Bandung: Alfabeta, 2006.

[12] M. Rijanta, R; Hizbaron, D.R; Baiquni, Modal Sosial Dalam Manajemen Bencana. Yogyakarta: Gadjah Mada University Press, 2018.

[13] L.U. Badan Pusat Statistik, "Luwu Utara Dalam Angka," Kabupaten Luwu Utara dalam Angka, p. 228, 2020.
[14] B. Bungin, Sosiologi Komunikasi. Jakarta: Prenada Media Group, 2014.

[15] H. Cangara, pengantar ilmu komunikasi, Keempat. Depok: Rajawali Pers, 2019.

[16] S.W. Littlejhon and K.A. Foss, Teori Komunikasi (Theories of Human Communication), 9th ed. Jakarta: Salemba Humanika, 2009.

[17] K.S. Haddow, George D; Haddow, Disaster Communications In A Changing Media World, Second Edi. Oxford: Butterworth-Heinemann, 2008.

[18] C.A. Johnson, "Social Capital and the Search for Information: Examining the Role of Social Capital in Information Seeking Behavior in Mongolia," J. Am. Soc. Inf. Sci. Technol., vol. 58, no. 6, pp. 883-894, 2007.

[19] E.R. Roem, "Persepsi Masyarakat Tentang Peran Media Cetak Lokal Dalam Mitigasi Bencana Alam,” J. Ilmu Komun., vol. 9, no. 2, pp. 143156, 2011.

[20] N. Christantyawati, "The Use of Social Media Amid Government, Mass Media, and Non Government Organisations Responsibilities Due to Haze Disaster," J. Kaji. Media, vol. 1, no. 1, pp. 50-59, 2017.

[21] B. Kusumasari, Manajemen bencana dan kapabilitas Pemerintah Lokal. Yogyakarta: Gava Media, 2014.

[22] H. Cangara, Perencanaan dan Strategi Komunikasi, Edisi Revi. Jakarta: Rajawali Pers, 2017. 